\title{
Polarised interleukin 8 secretion by HT 29/19A cells
}

\author{
K M Lammers, J Jansen, P B Bijlsma, M Ceska, G N J Tytgat, C L Laboisse, \\ $S \mathrm{~J} H$ van Deventer
}

\begin{abstract}
Interleukin 8 is a neutrophil chemotactic and stimulating cytokine induced by various inflammatory stimuli, including tumour necrosis factor, interleukin 1 , and endotoxin. The ability of HT 29/19A enterocytes to synthesise interleukin 8 was studied. The results show that interleukin 1 is an important stimulus for interleukin 8 synthesis and secretion by HT 29/19A cells, being more potent than tumour necrosis factor. The tumour necrosis factor and interleukin 1 induced interleukin 8 secretion by HT 29/19A cells was seen to be polarised according to the direction of stimulation. These results support the concept that mucosal cells (enterocytes) may play an important part in initiating mucosal inflammation. Furthermore, it is proposed that HT 29/19A cells constitute a tool to study stimulus directed polarised cytokine secretion.

(Gut 1994; 35: 338-342)
\end{abstract}

Interleukin 8 (IL 8) is a low molecular weight cytokine with neutrophil and $\mathrm{T}$ lymphocyte chemotactic and stimulating properties, ${ }^{1-3}$ that is synthesised and released by mononuclear cells, ${ }^{46}$ fibroblasts, ${ }^{78}$ keratinocytes, endothelial cells, ${ }^{10}$ hepatocytes," retinal pigment epithelial cells ${ }^{12}$ after stimulation by interleukin 1 (IL 1), tumour necrosis factor or endotoxin. Mitogens, lectins, and tumour promoters - that is, phorbal myristic acid, can also induce IL 8 synthesis. ${ }^{1314}$ High serum concentrations of IL 8 are seen in endotoxaemia and sepsis, ${ }^{1516}$ and local IL 8 production is increased in several inflammatory diseases. ${ }^{178}$ It is probable that in these conditions IL 8 , in conjunction with other cytokines such as IL 1 and tumour necrosis factor, attracts and subsequently activates neutrophils to release proteases and oxygen radicals, which may lead to tissue damage. Recently, we found high concentrations of IL 8 in large bowel biopsy specimens of patients with ulcerative colitis (Hommes DW, Van Deventer SJH, unpublished data) and identified mucosal cells (enterocytes) as one of the cellular sources (Radema and van Deventer, unpublished data). Raised cytokine concentrations have been shown in the gut lumen as well as in the mucosa of patients with ulcerative colitis. One study reported high tumour necrosis factor values in stools of patients suffering from inflammatory bowel diseases during the active phase of the disease. ${ }^{19}$ Other investigations reported high concentrations of IL 1 in mucosal biopsy specimens obtained from patients with inflammatory bowel disease. ${ }^{2021}$ In this context it became important to identify the stimuli that cause IL 8 secretion by mucosal cells. We therefore investigated the ability of enterocytes to respond to cytokines by secreting IL 8 in vitro. In addition, pharmacological agents (calcium ionophores, phorbol myristic acid) were used to explore the cellular mechanisms of this secretory response. The subclone $19 \mathrm{~A}^{22}$ of the human colon carcinoma cell line HT 29 was selected as model system because it forms monolayers of highly polarised cells that can respond to neuroendocrine secretagogues by secreting chloride, this functional differentiation being reminiscent of chloride secretory cells in the normal intestinal crypt. ${ }^{23}$ In other words, this clonal cell line typifies a phenotypically and functionally differentiated epithelial intestinal cell. Another advantage for using this cell clone is that it differentiates into highly differentiated cells when cultured in standard culture medium (glucose containing medium).

\section{Methods}

\section{CELL CULTURE}

HT 29/19A cells were grown in $25 \mathrm{~cm}^{2}$ cell culture flasks (Costar Cambridge, USA) in Dulbecco's Modified Eagle's medium containing $4.5 \mathrm{~g} / \mathrm{l}$ glucose (Life Technologies Ltd, Paisley Scotland). This medium was enriched with nonessential amino acids (1\%) (Life Technologies Ltd, Paisley Scotland), fetal bovine serum $(10 \%)$, and ciproxin $(0 \cdot 1 \%)$.

\section{STIMULATION}

Separate experiments were performed with cells grown in wells (Falcon, nr 3047, multiwell, 24 well, Becton \& Dickinson, New Jersey) and on microporous filters (Falcon nr 353095 , cyclo- o pore membrane with $0.45 \mu \mathrm{m}$, pore size, N diameter $9 \mathrm{~mm}$, Becton \& Dickinson, New ్ㅗ Jersey) placed in wells. In all experiments, the $\underset{Q}{ }$ cells were stimulated after complete confluency $\bullet$ was reached. Monolayer confluency was tested on several occasions both morphologically after Giemsa staining and by measuring the electrical resistance over the monolayer (mean resistance (SEM) was $\left.276(16) \Omega \times \mathrm{cm}^{2}, \mathrm{n}=19\right) .{ }^{24}$ On each occasion, the electrical resistance was measured for three hours. Permeability studies performed in Ussing chambers showed that the agents used 8 (including tumour necrosis factor and IL 1 ) did not affect the permeability of horseradish peroxidase, lactulose, and mannitol. Recombinant human tumour necrosis factor was obtained from Cetus Corporation (Emeryville, CA) and IL 1 from Medgenix (Fleurus, Belgium). Phorbol myristic acid and both calcium ionophores, ionomycin, and A23187 were obtained from Sigma Chemical Company Ltd (St Louis, USA). Several experiments were performed in this study. Firstly, cells grown in 24 well plate 
wells were stimulated with a combination of phorbol myristic acid (100 ng/ml) and a calcium ionophore (ionomycin, $50 \mu \mathrm{g} / \mathrm{ml}$ or A23187, $200 \mathrm{nM}$ ) during $2,4,6$, and 24 hours, at which time points the amount of IL 8 secreted was measured. In similar experiments tumour necrosis factor $(100 \mathrm{ng} / \mathrm{ml})$ and IL $1(140 \mathrm{pg} / \mathrm{ml})$ were used as the stimulus. Also, HT 29/19A cells were stimulated by graded concentrations of IL 1 (range: $1 \cdot 1 \mathrm{pg} / \mathrm{ml}$ to $140 \mathrm{pg} / \mathrm{ml}$ ) and tumour necrosis factor (range: $1 \cdot 1 \mathrm{pg} / \mathrm{ml}$ to $140 \mathrm{ng} / \mathrm{ml}$ ). The data presented represent mean values obtained in three experiments. In a second series of experiments, confluent HT 29/19A cell monolayers grown on microporous filters were stimulated apically or basally with tumour necrosis factor $(100 \mathrm{ng} / \mathrm{ml})$, IL $1(140 \mathrm{pg} / \mathrm{ml})$ or the phorbol myristic acid/A23187 combination. In this experiment the stimuli were added either above (upper compartment) or below (lower compartment) the cells, and the incubation time ranged from 24 to 48 hours. These experiments were performed in duplicate or triplicate and were repeated five to eight times.

\section{IL 8 ENZYME LINKED IMMUNOSORBENT ASSAY (ELISA)}

IL 8 was measured with a previously published ELISA. ${ }^{25}$ In brief, the ELISA wells were coated with anti-IL 8 monoclonal antibody $(5 \mu \mathrm{g} / \mathrm{ml})$. After removal of unbound antibody and blocking of the remaining non-specific binding sites, cell culture supernatants were added to the coated microtitre plate. After incubation, the plate was washed and a detecting antiserum enzyme conjugate of goat polyclonal anti-IL 8 antiserum was added to the wells. After further incubation and subsequent washings, the bound goat antiserum was detected with p-NPP $(1 \mathrm{mg} /$ $\mathrm{ml}$ in diethanolamine buffer). The optical density values of the samples were read at $450 \mathrm{~nm}$ on an automated ELISA plate reader. The detection limit of this assay in our hands was 15 $\mathrm{pg} / \mathrm{ml}$. The measured IL 8 values were corrected for the volume of the supernatant and then expressed as IL $8 / \mathrm{ng} / 10^{6}$ cells. One well contained about $14 \times 10^{5}$ cells, one filter contained about $5 \times 10^{6}$ cells.

\section{STATISTICAL ANALYSIS}

Differences between means were calculated with the Mann-Whitney U test, using the SPSS package (Chicago, Illinois). All reported significance levels represent two tailed $\mathrm{p}$ values.

\section{Results}

IL 1 AND TUMOUR NECROSIS FACTOR STIMULATE IL 8 SECRETION

After 24 hours of stimulation with tumour necrosis factor and IL 1, HT 29/19A cells secreted IL 8, whereas non-stimulated cells produced virtually no IL 8 . A time course experiment with tumour necrosis factor and IL 1 resulted in a time dependent increase of IL 8 during the first four hours after addition of the stimulus (Fig 1). IL 1 and tumour necrosis factor

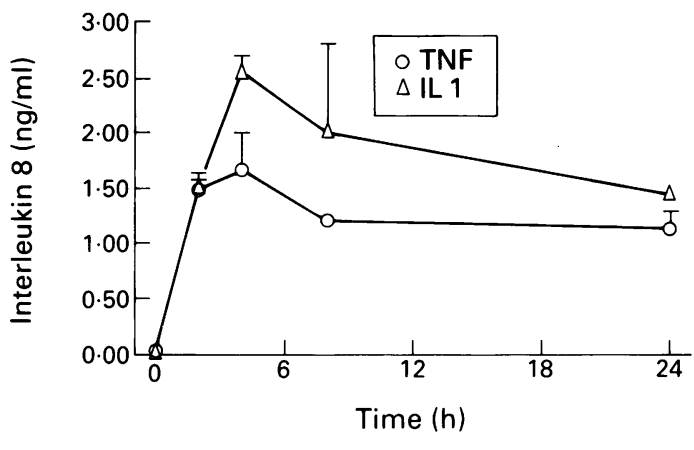

Figure 1: Time dependent IL 8 secretion. Secretion of IL 8 in time after stimulation with tumour necrosis factor (TNF) and IL 1 .

induced IL 8 synthesis in a dose dependent way, IL 1 being a more potent stimulus than tumour necrosis factor (Fig 2). The optimal dose for IL 1 was $4 \cdot 4 \mathrm{pg} / \mathrm{ml}$, for tumour necrosis factor $1 \cdot 1 \mathrm{ng} /$ $\mathrm{ml}$. The IL 8 concentrations measured at these optimal stimulation doses were $1 \cdot 13(0 \cdot 03)$ IL $8 /$ $\mathrm{ng} / \mathrm{ml}$ (for IL 1) and $1.53(0.23)$ IL $8 / \mathrm{ng} / \mathrm{ml}$ (for tumour necrosis factor).

\section{POLARISED IL 8 SECRETION}

Stimulation of HT $29 / 19$ A cell monolayers with tumour necrosis factor $(100 \mathrm{ng} / \mathrm{ml})$ and IL 1 (140 $\mathrm{pg} / \mathrm{ml}$ ) at both the apical and basolateral side (Fig 3) induced a polarised IL 8 secretion that was higher at the side where the stimulus had been added (Fig 4). Hence, addition of the stimulus (either tumour necrosis factor or IL 1) to the upper compartment caused secretion of IL 8 that was significantly higher to the apical direction. Conversely, stimulation from the lower compartment resulted in a preferential secretion of IL 8 to the basolateral direction. Tumour necrosis factor added to the upper compartment caused IL 8 secretion that was $5.49(2 \cdot 69)$ IL $8 / \mathrm{ng} / 10^{6}$ cells to the upper compartment, and $1 \cdot 41(0 \cdot 88)$ IL $8 / \mathrm{ng} / 10^{6}$ cells to the lower compartment $(p=0.01)$. Tumour necrosis factor applied in the lower compartment caused IL 8 secretion that amounted $7.96(1.72)$ IL $8 / \mathrm{ng} / 10^{6}$ cells to the lower compartment and $3.58(1.45)$ IL $8 / \mathrm{ng} / 10^{6}$ cells to the upper compartment $(\mathrm{p}<0.01)$. The amount of IL 8 secreted after IL 1 application to the upper compartment was $1 \cdot 69(0 \cdot 72)$ IL $8 / \mathrm{ng} /$ $10^{6}$ cells to the lower compartment and $2 \cdot 39(0 \cdot 1)$ IL $8 / \mathrm{ng} / 10^{6}$ cells to the upper compartment $(p=0 \cdot 25)$. IL 1 applied to the lower compartment, however, induced a much larger amount of IL 8 to be secreted to the lower compartment $\left(8.42(1.56)\right.$ IL $8 / \mathrm{ng} / 10^{6}$ cells) than to the upper compartment $\left(1.78(0.66)\right.$ IL $8 / \mathrm{ng} / 10^{6}$ cells $)$ $(\mathrm{p}<0.01)$. At the concentrations of $140 \mathrm{ng} / \mathrm{ml}$ (tumour necrosis factor) and $100 \mathrm{pg} / \mathrm{ml}$ (IL 1), tumour necrosis factor was a more powerful inducer of IL 8 secretion than IL 1 when applied in the upper compartment, $5.49(2.69) v 2.39$ $(0 \cdot 1)$ IL $8 / \mathrm{ng} / 10^{6}$ cells in the upper compartment $(p<0.01)$. When applied below, no significant differences in IL 8 secretion to the lower compartment were seen between tumour necrosis factor (7.96 (1.72) IL 8/ng/10 $\left(8.42(1 \cdot 56)\right.$ IL $8 / \mathrm{ng} / 10^{6}$ cells). The polarised stimulus directed pattern of IL 8 secretion by 


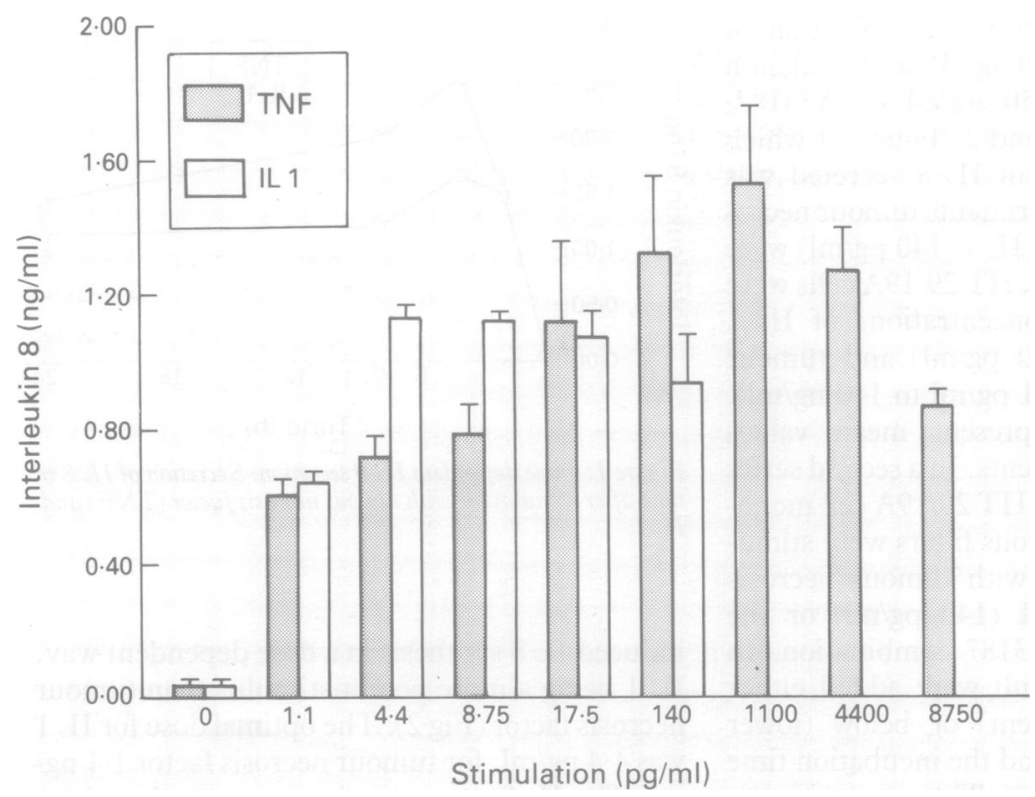

Figure 2: Dose range stimulations. Dose dependent IL 8 secretion by HT 29/19A cells. Stimulation was performed with tumour necrosis factor $(T N F)$ and IL $I$ in the concentration ranges of $1 \cdot 1 \mathrm{pg} / \mathrm{ml}$ to $140 \mathrm{ng} / \mathrm{ml}$ and $1 \cdot 1 \mathrm{pg} / \mathrm{ml}$ to $140 \mathrm{pg} / \mathrm{ml} \mathrm{respectively.} \mathrm{The} \mathrm{cells} \mathrm{were}$ incubated for 24 hours in the presence of either tumour necrosis factor or IL 1 .

HT 29/19A cells was seen after stimulation with either suboptimal, optimal or supraoptimal concentrations of tumour necrosis factor and IL 1. To discover if IL 1 or tumour necrosis factor caused a change in the integrity of the enterocyte

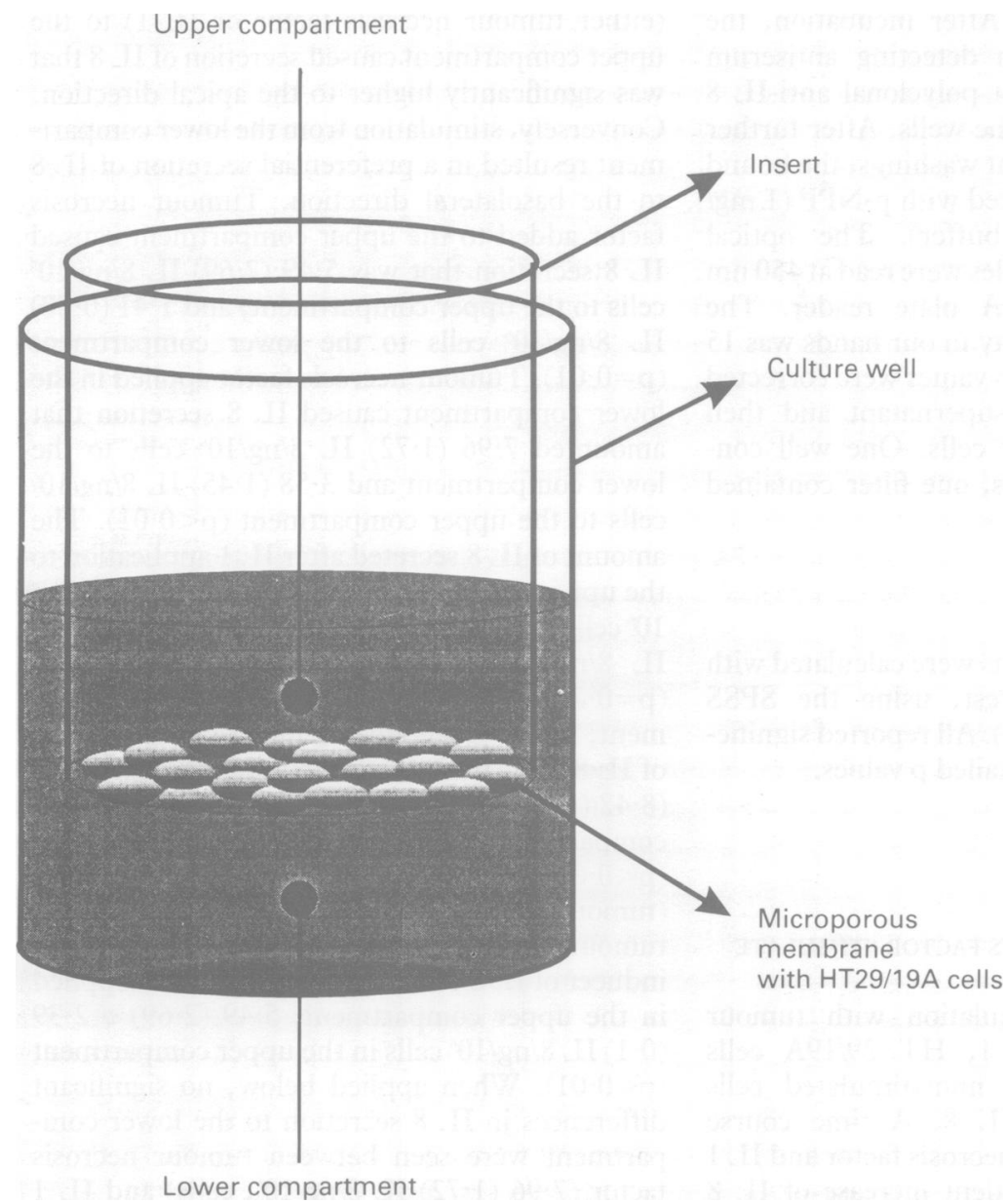

Figure 3: The application system used at the filter experiments. Stimuli were applied either in the upper compartment or in the lower compartment. monolayer, the electrical resistance was measured. The results of these experiments suggest that the cytokines used do not change junctional permeability or cell viability (mean resistance (SEM) was $\left.276(16) \Omega \times \mathrm{cm}^{2}\right)$ and did not change.

STIMULATION OF IL 8 SECRETION WITH PHORBOL MYRISTIC ACID/CALCIUM IONOPORE

After stimulation with phorbol myristic acid/ ionomycin or phorbol myristic acid/A23187 combinations, HT 29/19A cells secreted large amounts of IL 8. After four hours of stimulation with phorbol myristic acid/ionomycin and phorbol myristic acid/A23187 the IL 8 concentration in the supernatant increased to 3.01 $(0.51) \mathrm{ng} / \mathrm{ml}$ and $1.69(0.05) \mathrm{ng} / \mathrm{ml}$ respectively. After six hours the IL 8 concentrations further increased to $5 \cdot 72(0 \cdot 20) \mathrm{ng} / \mathrm{ml}$ and $5.9(0 \cdot 16) \mathrm{ng} /$ $\mathrm{ml}$, and after 24 hours to $5.86(0.03) \mathrm{ng} / \mathrm{ml}$ and $9.64(2 \cdot 71) \mathrm{ng} / \mathrm{ml}$ (a 13 to 21 -fold increase). Surprisingly, in experiments with cells grown on microporous filters the combination of phorbol myristic acid/A23187 induced only IL 8 secretion when applied in the upper compartment. No IL 8 secretion was induced when phorbol myristic acid/A23187 was added in the lower compartment (Fig 4). To discover if phorbol myristic acid/A23187 applied to the lower compartment was adsorbed by the microporous filter, we cultured HT 29/19A cells in wells and stimulated the cells for 24 hours with phorbol myristic acid/A23187, which was added in a microporous filter insert that previously had been coated with HT 29/19A matrix proteins. In this system phorbol myristic acid/A23187 induced an IL 8 secretion from the HT 29/19A cells, showing that phorbol myristic acid/A23187 was not absorbed to the microporous filter. The combined action of phorbol myristic acid/ calcium ionophore did not modify the electrical resistance of the monolayers.

\section{Discussion}

Our results show that IL 8 is secreted by HT 29/ $19 \mathrm{~A}$ cells after stimulation with tumour necrosis factor and IL 1. These data complement and extend previous findings showing that primary cultures of human airway epithelial cells ${ }^{26}$ as well as human bronchial epithelial cell lines ${ }^{27} 28$ can secrete IL 8 upon stimulation with various stimuli. After stimulation with tumour necrosis factor and IL 1 , the amount of IL 8 released progressively increased during the first four hours, suggesting that IL 8 was continuously produced and not merely released from internal storage. This finding is in line with other results showing that human bronchial epithelial cell lines express IL 8 in response to the inflammatory mediator tumour necrosis factor primarily by increasing the rate of transcription of the gene. ${ }^{27}$ The IL 8 concentration in both experiments decreased slightly, possibly because of degradation of IL 8. The decrease seen in the IL 8 concentration may have also resulted from a cytotoxic effect, because IL 1 in concentrations higher than $140 \mathrm{pg} / \mathrm{ml}$ was toxic for HT $29 / 19 \mathrm{~A}$ cells. Appreciable IL 8 induction was seen when 


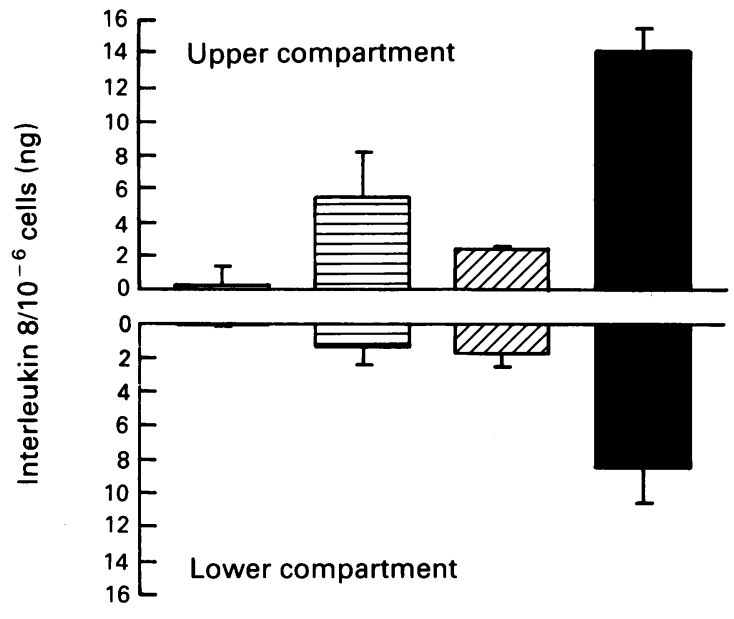

Stimulus above

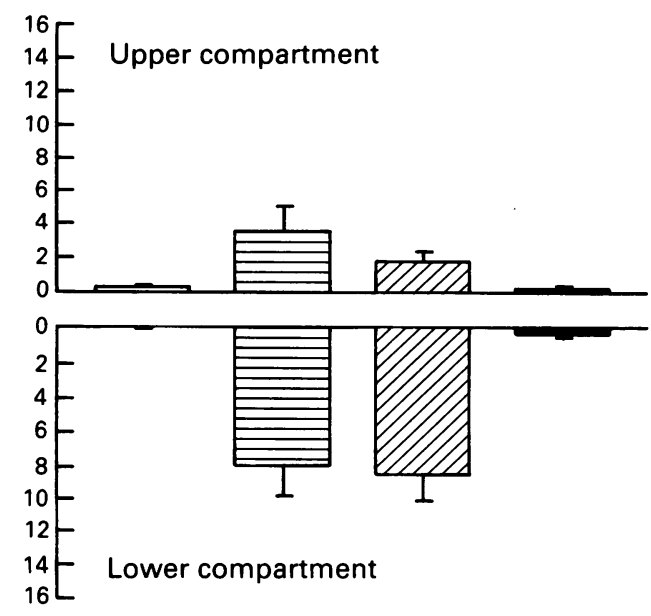

Stimulus below

Figure 4: Stimulation in upper or lower compartment: polarised IL 8 secretion. Polarised stimulus directed secretion of IL 8 by HT 29/19A cells after stimulation with IL 1, tumour necrosis factor, and phorbol myristic acid/A23187 in the upper or lower compartment. Open bars represent the control wells, the striped bars represent the tumour necrosis factor stimulated wells, the hatched bars represent the IL 1 stimulated wells, and the solid bars represent stimulation with phorbol myristic acid/A23187. Phorbol myristic acid/A23187 applicated in the lower compartment was restricted by the filter.

tumour necrosis factor and IL 1 were added in concentrations that can be found in the mucosa of patients with ulcerative colitis. ${ }^{2021}$ It remains unknown whether these cytokines trigger the same intracellular signalling pathways. It was recently shown, however, that viral infection can stimulate IL 8 secretion from bronchial epithelial cells in an IL 1 independent manner. ${ }^{26}$ This finding supports the concept that IL 8 secretion may be triggered by several pathways.

Surprisingly, after addition of the stimuli (tumour necrosis factor, IL 1) to the upper (apical) or lower (basolateral) compartments, HT 29/19A cells could 'sense' the direction from which they were stimulated and secreted IL 8 predominantly into that direction. The mechanisms that cause such polarised IL 8 secretion are incompletely understood. In the process of transport of membrane bound or secretory proteins, reorganisation of the cytoskeleton is considered to play an important part. It is well known that cytokines, such as tumour necrosis factor, may cause a rapid change in the cytoskeletal organisation in various cells. ${ }^{29}$ Cytoskeletal reorganisation that results from intercellular contact of immune cells, such as $T$ cellB cell contact, may direct cytokines intracellularly specifically to the area of the cell-cell contact. $^{30}$ Our preliminary results, however, seem to refute an important role of actin filaments in the sorting of IL 8, as cytochalasin B, a drug that interferes with the actin filaments did not perturbate its sorting (data not shown). Another hypothesis is that IL 1 or tumour necrosis factor may cause changes in the apical to basolateral area ratio upon binding to their specific receptors. In fact the possibility exists that such changes may occur because it has recently been shown that an exogenous stimulus - that is, a different growth support - can induce a modification of the apical to basolateral surface area ratio of cultured MDCK cells. ${ }^{31}$ Consequently the secretory rate of IL 8 would be increased at the side showing the maximal surface area.
The combined action of phorbol myristic acid/ calcium ionophore resulted in IL 8 secretion by the HT 29/19A cells. Phorbol myristic acid/ calcium ionophore as a stimulus showed a time dependent IL 8 secretion similar to tumour necrosis factor. The phorbol myristic acid/ calcium ionophore combination, however, was only effective in stimulating IL 8 release when applied to the upper compartment. Experiments performed to check if phorbol myristic acid/ A23187 applied in the lower compartment was restricted by the microporous filter, showed that the lack of IL 8 secretion could not be explained by adsorption of phorbol myristic acid/A23187 to the microporous filters. After 24 hours of apical stimulation phorbol myristic acid/A23187 presented within a microporous insert could induce IL 8 secretion comparable with phorbol myristic acid/A23187 applied on the cells. One possible explanation for this finding is that binding of phorbol myristic acid to phospholipids in the apical membrane of HT 29/19A cells, in particular phosphatidylserine, ${ }^{32}$ is necessary to induce signal transduction and initiate gene transcription. Viral transfection studies in MDCK epithelial cells are in accordance with this hypothesis because viruses that budded from the apical plasma membrane were enriched in phosphatidylserine, whereas viruses budding from the basolateral surface were not. ${ }^{33}$ It has recently been reported that apical application of phorbol myristic acid, but not basolateral application, induced $\mathrm{Cl}^{-}$secretion by T84 mucosal cells, and this result led the authors to conclude that phorbol myristic acid induced an apical subcellular pool of protein kinase C. ${ }^{34}$

Presumably, IL 8 plays an important part in inflammatory bowel disease, in particular in ulcerative colitis, which is histologically characterised by large amounts of infiltrating neutrophils. Increased IL 8 mRNA concentrations were detected in mucosal biopsy specimens of patients suffering from inflammatory bowel disease. ${ }^{35}$ The IL 8 that is released basolaterally by enterocytes may participate in the recruit- 
ment and subsequent activation of neutrophils. ${ }^{36}$ At present we have no explanation for the biological importance of apical secretion of IL 8 by enterocytes. Interestingly, it has been recently reported that IL 1 can be a growth factor for Escherichia coli, ${ }^{37}$ and bacteria can produce an IL 1 like activity themselves. ${ }^{37}$ IL 1 has been detected in mucosal cells in vivo ${ }^{2021}$ and in nondifferentiated mucosal cells in experimental colitis. $^{38}$ Enterocytes and bacteria may therefore interact by means of cytokine secretion. Although the mucosal cytokine networks have been incompletely characterised, the ability of mucosal cells to synthesise IL 1 and IL 8 is in accordance with the hypothesis that enterocytes, in addition to endothelial cells, peripheral blood monocytes infiltrated in the mucosa, and resident lamina propria mononuclear cells play an important part in the mucosal inflammatory cascade. In conclusion, HT 29/19A cells can produce large amounts of IL 8 after stimulation by IL 1 and tumour necrosis factor, at concentrations that may occur in inflammatory bowel disease. IL 8 secretion by HT 29/19A cells is polarised according to the direction of the stimulus. Therefore, HT 29/19A cells may be used to investigate the mechanisms of polarised cytokine release in more detail.

We are indebted to Dr J A Groot (Department of Experimental Zoology, University of Amsterdam) for his help in culturing HT 29 cells. We thank Jan Wouter ten Cate and Harry Büller for the helpful discussions. Dr S J H van Deventer is supported by a
grant from the Royal Dutch Academy of Arts and Sciences. P B Bijlsma is supported by a grant from Nutricia.

1 Matsushima K, Baldwin ET, Mukaida N. 1992. Interleukin-8 and MCAF: novel leukocyte recruitment and activating cytokines. Chem Immunol 1984; 51: 236-65.

2 Westwick J, Li SW, Camp RD. Novel neutrophil-stimulating peptides. Immunol Today 1989; 10: 146-7.

3 Larsen CG, Anderson AO, Appella E, Oppenheim JJ Matsushima K. The neutrophil-activating protein (NAP-1) is also chemotactic for T-lymphocytes. Science 1989; 243 $1464-6$

4 Yoshimura T, Matsushima K, Tanaka S, Robinson EA, Appella E, Oppenheim JJ, et al. Purification of a human monocyte-derived neutrophil chemotactic factor that has peptide sequence similarity to other host defense cytokines. Proc Natl Acad Sci USA 1987; 84: 9233-7.

5 Walz A, Peveri P, Aschauer H, Bagglioni M. Purification and amino acid sequencing of NAF, a novel neutrophil-activating factor produced by mo

6 Colditz I, Zwahlen R, Dewald B, Bagglioni M. In vivo inflammatory activity of neutrophil-activating factor, a nove chemotactic peptide derived from human monocytes. $A m \mathcal{J}$ Pathol 1989; 134: 755-60.

7 Larsen G, Anderson AO, Oppenheim JJ, Matsushima K. Production of interleukin-8 by human dermal fibroblast and keratinocytes in response to interleukin-1 or tumour necrosis factor. Immunology 1989; 68: 31-6.

8 Schröder JM, Sticherling M, Henneicke HH, Preissner WC Christophers E. IL-1 $\alpha$ or tumor necrosis factor- $\alpha$ stimulate release of three NAP-1/IL-8-related neutrophil chemotactic proteins in human dermal fibroblasts. F Immunol 1989; 144: 2223-32.

9 Sica M, Matsushima K, Van Damme J, Wang JM, Polentarutti N, Dejana E, et al. IL-1 transcriptionally activates the neutrophil chemotactic factor/IL
endothelial cells. Immunology $1990 ; 69: 548-53$.

10 Strieter RM, Kunkel SL, Showell DG, Remick DG, Phan SH, Ward PA, et al. Endothelial cell gene expression of neutrophil chemotactic factor by TNF- $\alpha$, LPS and IL-1 $\beta$ Science 1989; 243: 1467-9.

11 Thornton AJ, Strieter RM, Lindley I, Baggiolini M, Kunke $\mathrm{SL}$. Cytokine gene expression of a neutrophil chemotactic factor/IL-8 in human hepatocytes. F Immunol 1990; 144: 2609-13.

12 Elner VM, Strieter RM, Elner SG, Baggiolini M, Lindley I, Kunkel SL. Neutrophil chemotactic factor (IL-8) gene expression by cytokine-treated retinal pigment epithelial cells. Am 7 Pathol 1990; 136: 745-50.

13 Gregory H, Young J, Schröder JM, Mrowietz U, Christophers E. Structure determination of a human lymphocyte derived neutrophil activating peptide (lynap). Biochem Biophys Res 1.8 $83-90$

14 Schröder JM, Mrowietz U, Morita E, Christophers E. Purification and partial biochemical characterization of a human monocyte-derived, neutrophil-activating peptide that lacks interleukin-1 activity. F Immunol 1987; 139: 3474 83.

15 Van Zee KJ, DeForge LE, Fischer E, Marano MA, Kenney JS, Remick DG, et al. IL-8 in septic shock, endotoxemia and after IL-1 administration. F Immunol 1991; 146: 3476-82.

16 Martich GD, Danner RL, Ceska M, Suffredini AF. Detection of interleukin 8 and tumor necrosis factor in normal humans after intravenous endotoxin: the effect of antiinflammatory agents. F Exp Med 1991; 173: 1021-4.

17 Schröder J-M. Generation of NAP-1 and related peptides in psoriasis and other inflammatory skin diseases. In: Sorg C, ed. Interleukin-8 (NAP-1) and related chemotactic cytokines. Basel: Karger, 1992: 54-77.

18 Seitz M, Dewald B, Gerber N, Baggiolini M. Enhanced production of neutrophil-activating peptide-1/interleukin-8 production of neutrophil-activating peptide-1/interleuki

19 Braegger CP, Nicholls S, Murch SH, Stephens S, MacDonald TT. Tumour necrosis factor alpha in stool as a marker of intestinal inflammation. Lancet 1992; 339: 89-91.

20 Ligumsky M, Simon PL, Karmeli F, Rachmilewitz D. Role of interleukin-1 in inflammatory bowel disease-enhanced production during active disease. Gut 1990; 31: 686-9.

21 Brynskov J, Tvede $N$, Andersen $C B$, Vilien $M$. Increased concentrations of interleukin-1 $\beta$, interleukin-2, and soluble interleukin-2 receptors in endoscopical mucosal biopsy specimens with active inflammatory bowel disease. Gut 1992; 33: 55-8

22 Augeron $\mathrm{Ch}$, Laboisse CL. Emergence of permanently differentiated cell clones in a human colonic cancer cell line in culture after treatment with sodium butyrate. Cancer Res 1984; 44: 3961-9.

23 Augeron C, Maoret JJ, Laboisse CL, Grasset E. Permanently differentiated cell clones isolated from the human colonic adenocarcinoma cell line HT 29: possible models for the study of ion transport and mucus production. In: Alvarado $\mathrm{F}$, Van Os CH, eds. Ion gradient-coupled transport. INSERM symposium no 26. Amsterdam: Elsevier 1986: 363-6.

24 Heyman M, Crain-Denoyelle AM, Nath SK, Desjeux JF. Quantification of protein transcytosis in the human colon

25 Ceska M, Effenberger F, Peich P, Pursch E. Purification and characterization of monoclonal and polyclonal antibodies to neutrophil activation peptide (NAP-1). The development of highly sensitive ELISA methods for the determination of NAP-1 and Anti-NAP-1 antibodies [Abstract]. Cytokines NAP-1 and

26 Choi AMK, Jacoby DB. Influenza virus-A infection induces interleukin-8 gene expression in human airway epithelia cells. FEBS Lett 1992; 309: 327-9.

27 Nakamura H, Yoshimura K, Jaffe HA, Crystal RG. Interleukin-8 gene expression in human bronchial epithalial cells. F Biol Chem 1991; 266: 19611-7.

28 Nakamura H, Yoshimura K, Moelvaney NG, Crystal RG. Neutrophil elastase in respiratory epithelial lining fluid of individuals with cystic fibrosis induces interluekin-8 gene expression in a human bronchial epithelial cell line. $\mathcal{F}$ Clin Invest 1992; 89: 1478-84.

29 Camussi G, Turello E, Tetta C, Bussolino F, Baglioni CAF Tumor necrosis factor induces contraction of mesangial cells Tumor necrosis factor induces contraction of mesangial cells
and alters their cytoskeletons. Kidney Int 1990; 38: 795-802.

30 Kupfer A, Mosmann TR, Kupfer H. Polarized expression of cytokines in cell conjugates of helper $T$ cells and splenic B cells. Proc Natl Acad Sci USA 1991; 88: 775-9.

31 Butor C, Davoust J. Apical to basolateral surface area ratio and polarity of MDCK cells grown on different supports. Exp Cell Res 1992; 203: 115-27.

32 Nishizuka $Y$. The role of protein kinase $C$ in cell surface signa transduction and tumor promotion. Nature 1984; 308: 693-7.

33 Handler JS. Overview of epithelial polarity. Annu Rev Physiol 1989 ; $51: 729-40$.

34 Lindeman RP, Chase HS. Protein kinase-C does not participate in carbachol's secretory action in T84 cells. Am $\mathcal{F}$ Physiol 1992; 263: C140-6.

35 Isaacs KL, Balfour Sartor R, Haskill S. Cytokine messenger RNA profiles in inflammatory bowel disease mucosa RNA profiles in inflammatory bowel disease mucosa detected by polymerase chain

36 Van Damme J. Chemotactic cytokines: biology of the inflammatory peptide supergene family. Granulocyte and monocyte chemotactic factors: stimuli and producer cells. Adv Exp Med Biol 1991; 305: 1-9.

37 Porat R, Clark BD, Wolff SM, Dinarello CA. Enhancement of growth of virulent strains of Escherichia coli by interleukin1. Science 1992; 254: 430-2.

38 Radema SA, Van Deventer SJH, Cerami A. Interleukin $1 \beta$ is expressed predominantly by enterocytes in experimental colitis. Gastroenterology 1991;100: 1180-6. 